\title{
International Investment Law, Time, and Economics: Fixing the Length of Economic Crises as a Costs-Allocation Tool between Host States and Foreign Investors
}

\author{
Alberto Alvarez-Jimenez \\ University of Waikato, New Zealand \\ Email: alberto.alvarez-jimenez@waikato.ac.nz
}

\begin{abstract}
The case law on non-precluded measures clauses, when they are successful, and the customary rule of necessity, when it fails, transfers significant risks to foreign investors and host States, respectively, during severe economic crises. Some risk-sharing mechanisms should be explored to achieve a more balanced result. This article presents the policy reasons in support of this approach and its normative basis: the principle of acceptable compensation, and illustrates that one way to introduce such mechanisms is through the determination by investor/State tribunals of the length of the breakdown, which is marked by the dates for its beginning and end. The article discusses economic research on when crises conclude, which could be useful to tribunals, and explores the determination on the beginning of economic collapses as a risk-sharing tool and shows how decisions of the Argentinean saga have achieved this result.
\end{abstract}

Keywords: customary rule of necessity; economic crises; investment arbitration; non-precluded measures clauses; risksharing mechanisms

\section{Introduction}

The case law on non-precluded measures clauses in international investment agreements (IIAs) rendered by international arbitration tribunals under the jurisdiction of the International Centre for the Settlement of Investment Disputes (ICSID) remains controversial. ${ }^{1}$ In recent years, some of this case law has indicated that the successful invocation of nonprecluded measures clauses (NPM clauses) prevents violations of the applicable treaty. ${ }^{2}$ Consequently, according to such case law, the State owes no compensation to investors for damages caused by measures aimed at coping with the crisis during situations of emergency, ${ }^{3}$

\footnotetext{
${ }^{1}$ The case law has been generated by litigation against Argentina resulting from its 2001 economic collapse and its invocation of the non-precluded measures clause included, among others, in Article XI of the US-Argentina Bilateral Investment Treaty:
}

This Treaty shall not preclude the application by either Party of measures necessary for the maintenance of public order, the fulfillment of its obligations with respect to the maintenance or restoration of international peace or security, or the Protection of its own essential security interests.

Treaty between the United States of America and the Argentine Republic Concerning the Reciprocal Encouragement and Protection of Investment, US-Argentina. Signed on 14 November 1991.

${ }^{2}$ See Sempra Energy International v. Argentine Republic, Decision on Annulment, ICSID Case No. ARB/02/16, 29 June 2010, at para. 200 [Sempra Annulment Decision].

${ }^{3}$ See CMS Gas Transmission Company v. Argentine Republic, Decision of Annulment, ICSID Case No. ARB/01/8, 25 September 2007, at para. 146 [CMS Annulment Decision]. 
and such measures may be permanent and need not be removed as soon as the emergency subsides. ${ }^{4}$

Although this case law is exceptional, since the successful invocation of NPM clauses has been rare, ${ }^{5}$ it transfers a great deal of the risks during situations of emergency to investors, while the quite strict approach of the customary rule of necessity embodied in Article 25 of the International Law Commission's Articles on Responsibility of States for Internationally Wrongful Acts (the customary rule) does just the opposite. ${ }^{6}$

As to the effects of Article 25, Article 27 of the ILC's Articles establishes that compensation can be negotiated by the State invoking necessity, ${ }^{7}$ but it is limited to material loss, and its definition is narrower than the notion of compensation for wrongful acts. ${ }^{8}$ Furthermore, Article 27 also provides that compliance with the international obligation must take place once the situation of necessity ends. ${ }^{9}$

In Case Concerning the Gabcikovo-Nagymaros Project (Hungary/Slovakia), ${ }^{10}$ the International Court of Justice ruled that Article 25 had to be interpreted very narrowly, since it served to excuse wrongful acts under international law; and that the requirements had to be satisfied cumulatively by the State invoking necessity. ${ }^{11}$ The bar is certainly high for States, a fact evidenced by Argentina's frequent failure when invoking this provision. ${ }^{12}$ As can be seen, the interpretation of Article 25 advocated by the Court substantially transfers risks to States during economic collapses.

\footnotetext{
${ }^{4}$ See Continental Casualty Company v. Argentine Republic, Award, ICSID Case No. ARB/03/9, 5 September 2008, at paras. 303-304 [Continental].

${ }^{5}$ See ibid., at paras. 236, and LGÆE Energy Corp. v.. Argentine Republic, Decision on Liability, ICSID Case No. ARB/02/1, 3 October 2006, at para. $266[L G \& E]$.

${ }^{6}$ It provides:
}

1. Necessity may not be invoked by a State as a ground for precluding the wrongfulness of an act not in conformity with an international obligation of that State unless the act:

(a) is the only means for the State to safeguard an essential interest against a grave and imminent peril; and

(b) does not seriously impair an essential interest of the State or the State towards which the obligation exists, or of the international community as a whole.

2. In any case, necessity may not be invoked by a State as a ground for precluding wrongfulness if:

(a) the international obligation in question precludes the possibility of invoking necessity; or

(b) the State has contributed to the situation of necessity.

International Law Commission, Articles on Responsibility of States for Internationally Wrongful Acts, at 6-7. General Assembly Resolution 56/83. 20 January 2002 [ILC's Articles], www.un.org/en/ga/search/view_doc.asp?symbol=A/RES/ $56 / 83$.

${ }^{7}$ See International Law Commission, Articles on Responsibility of States for Internationally Wrongful Acts, with Commentaries 2001, at 86 [ILC Commentaries]. http://legal.un.org/ilc/texts/instruments/english/commentaries/9_6_2001.pdf.

${ }^{8}$ See ibid. at 86 .

${ }^{9}$ See ibid. at 85 .

${ }^{10}$ International Court of Justice, Case Concerning the Gabcikovo-Nagymaros Project (Hungary/Slovakia), Judgment of 25 September 1997 IC.J. Reports 1997, p. 7.

${ }^{11}$ See ibid., at para. 51 .

${ }^{12}$ In the following cases, Argentina's invocation of Article 25 has failed: see CMS Gas Transmission Company v. the Argentine Republic, Award, ICSID Case No. ARB/01/8, 12 May 2005, at paras. 57 and 65 [CMS]; on the matter of an UNCITRAL Arbitration, National Grid P.L.C. v. Argentine Republic, Award, 3 November 2008, at paras. 257-262 [National Grid]; Suez, Sociedad General de Aguas de Barcelona S.A., and Vivendi Universal S.A. v. the Argentine Republic; AWG Group v. the Argentine Republic, Decision on Liability, ICSID Case No. ARB/03/19, 30 July 2010, at paras. 260-265 $[A W G]$; Total S.A. v. the Argentine Republic, Decision on Liability, ICSID Case No. ARB/04/1, 27 December 2010 , at paras. 220-224 [Total Decision on Liability]; EDF International S.A., SAUR International S.A. and Leon Participaciones Argentinas S.A. v. Argentine Republic, Award, ICSID Case No. ARB/03/23, 11 June 2012, at paras. 1171-1176 [EDF]; and Impregilo S.p.A v. Argentine Republic, Award, ICSID Case No. ARB/07/17, 21 June 2011, at paras. 344-359 [Impregilo]. 
Thus, there is room for improvement as to the risk-sharing mechanisms between States and investors during economic collapses in the case law under these two provisions (Article XI of the BIT and Article 25 of the ILC Draft). ${ }^{13}$ Indeed, investor/State tribunals can mitigate the effects of an NPM clause or the customary rule in two events: (i) when the defence based on the NPM clause invoked by the host State is successful; and (ii) when the defence based on the customary rule fails. Finally, the instrument to introduce risk-sharing mechanisms is the determination of the length of the crisis for the purpose of the measure of the compensation to be paid to the claimant investor by the host State.

To develop this objective this article has four sections in addition to this introduction. The next section identifies the policy reasons behind the need to introduce risk-sharing mechanisms, the main normative basis of the power of investor/State tribunals to introduce such mechanisms, and the limits of this power. The third section deals with how tribunals could determine a date for the end of an economic collapse in order to allocate risks between investors and host States. This section also shows that tribunals dealing with the Argentinean saga have already done so. Tribunals can expand the length of the collapse to reduce the compensation when the defence based on the customary rule has failed; and they can reduce the length in a way that allows the investor to be compensated for measures adopted after the breakdown has ceased, in the tribunal's view, when the defence based on the NPM clause is successful. This section also discusses recent research in economics on when crises end, which could be useful to tribunals making this determination. The fourth section explores the topic of the beginning of economic collapses as a risk-sharing tool. The fifth section concludes.

\section{Policy Justifications for and Normative Bases of Risk-Sharing Mechanisms during Economic Crises}

There are several policy reasons underlying the need for risk-sharing mechanisms during economic collapses in the application of NPM clauses. Sykes has already mentioned one: the need to prevent moral hazard. ${ }^{14}$ If States can transfer significant risks to investors during economic collapses thanks to the successful invocation of non-precluded measures clauses and their noncompensation effect, there are few incentives for host States to be as cautious as possible in the design of the measures aimed at dealing with the crises.

There is also a second policy reason for the introduction of this mechanism when NPM clauses are successful. Lack of compensation to investors means in the long run that they might react to such jurisprudence by requesting ex ante an additional premium for their investments from States party to IIAs, with similar clauses to cover the risk of losses during potential severe crises. ${ }^{15}$ These crises do not often occur in States, and a jurisprudence that transfers significant risks to investors may not wind up favouring host States in the long term, since they might eventually start transferring resources to investors well in advance of a crisis taking place, and even to investors who may never be affected by them. When this situation happens, the efficiency of such transfers may not be evident from a State's perspective. On the contrary, an approach to the interpretation of NPM clauses that allows States and investors to share

\footnotetext{
${ }^{13}$ The fact that NPM clauses have hardly been successful in the litigation of the Argentinean saga does not mean that the introduction of a risk-sharing mechanism is futile. Quite the contrary: the existence of the mechanism is important precisely when the clause is successful, and for the benefit of the investor. Likewise, the fact that the customary rule usually fails does not make useless the existence of a risk-sharing instrument. The very fact of the lack of success prompts the need for a risksharing mechanism for the benefit of the respondent host State that endured the given economic collapse.

${ }^{14}$ See Alan O. Sykes, 'Economic "Necessity” in International Law', 109 American Journal of International Law (2015), 296, 299,313 , and 319 .

${ }^{15}$ See William W. Burke-White and Andreas von Staden, 'Investment Protection in Extraordinary Times: The Interpretation and Application of Non-precluded Measures Provisions in Bilateral Investment Treaties', 48 Virginia Journal of International Law (2008), 307, 402.
} 
risks in severe, abnormal circumstances creates an incentive for the reduction of the said premium and of the associated transfers, and, in the end, for a better allocation of public resources.

The need for risk-sharing mechanisms in the application of the customary rule during economic collapses is evident due to its strict criteria. The defence will usually fail in investment disputes mostly because of the existence of other means or of a substantial contribution by the host State. So, if the effect of this failure is that the claimant investor will be fully compensated as if the crisis had not taken place, then IIAs become insurance policies against economic collapses, ${ }^{16}$ something IIAs are not meant to be. A risk-sharing result is the mechanism that prevents such an outcome: there is a crisis, and even if the investor prevails in litigation, it will incur some costs.

The proposal put forward in this article has, though, a caveat. The purpose is not to always achieve an equal allocation of risks between host States and foreign investors during economic collapses.

From a legal perspective, mitigating the effects of the application of NPM clauses or the customary rule through cost-sharing mechanisms has a prominent normative basis in the wellestablished criterion of acceptable outcome in the measurement of compensation. As the International Law Commission has indicated:

As to the appropriate heads of compensable damage and the principles of assessment to be applied in quantification, these will vary, depending upon the content of particular primary obligations, an evaluation of the respective behaviour of the parties and, more generally, a concern to reach an equitable and acceptable outcome. ${ }^{17}$

The normative basis has, though, limits worth exploring as well. Cost sharing should not be used as a back-door tool to ignore the consequences mandated by the applicable IIA. The proposal suggested here does not, then, transform investor/State tribunals into re-drafters of the applicable treaty, but keeps them within the scope of the judicial function assigned to them.

Nor can cost-sharing effects be of such a nature that they become an expression of adjudication ex aequo et bono, if the parties have not agreed to it pursuant to Article 42.3 of the Convention on the Settlement of Investment Disputes between States and Nationals of Other States. ${ }^{18}$ It is worth mentioning that, without the express consent of the parties, decisions ex aequo et bono (according to what is equitable and good) can be annulled by virtue of Article 52(b) of the ICSID Convention due to manifest excess of powers. ICSID Ad Hoc Annulment Committees have sometimes so determined, ${ }^{19}$ and, to be sure, the proposal put forward here does not pretend to be equated to such decisions.

\subsection{Economic Efficiency v. Cost-sharing Mechanisms}

Apparently, cost-sharing mechanisms are not desirable. For instance, Kaplov is of the view that governments should never compensate investors for regulatory changes, which includes legal changes caused to address severe economic crises. In his words:

Compensation shifts part of the long-run cost of private investment to the government and thus distorts an otherwise decisionmaking process. It is socially desirable for investors to

\footnotetext{
${ }^{16}$ See infra note 47 and accompanying text.

${ }^{17}$ ILC, Commentaries, supra note 7, at 100.

${ }^{18}$ Convention on the Settlement of Investment Disputes between States and Nationals of Other States, opened for signature at Washington on 18 March 1965 [ICSID Convention].

${ }^{19}$ See International Centre for Settlement of Investment Disputes, Updated Background Paper on Annulment for the Administrative Council of ICSID, 5May 2016, at para. 93 [ICSID Paper on Annulment], https://icsid.worldbank.org/en/ Documents/resources/Background\%20Paper\%20on\%20Annulment\%20April\%202016\%20ENG.pdf.
} 
take into account the prospect for governmental reform; compensation eliminates this incentive by insulating investors from an important element of downside risk. ${ }^{20}$

To Kaplov, there is no difference between the risk of legal reform and business risks. Governments do not compensate for the latter they should not do it for the former. ${ }^{21}$ The risk of legal reform can be handled through markets in either two ways: insurance or by spreading risk. $^{22}$ The market is efficient and therefore there is no economic justification for government mitigation. ${ }^{23}$ Kaplov points out that the existence of compensation reduces investors' risks and then leads to overinvestment. ${ }^{24}$

Kaplow asks whether relief could be justified by a fair distribution of benefits and burdens of changes in government policy. He admits that his analysis of the role of fairness is limited, ${ }^{25}$ but nonetheless indicates that the issue can be properly dealt with under the framework of the economic analysis of risk. ${ }^{26}$ Accordingly, it is fair not to compensate an individual who bears a significant burden, when there are market instruments to cover the risk of legal change.

Valuable as it is, Kaplow's analysis is not fully applicable here for a number of reasons. First, he is right in the sense that foreign investors may get political risk insurance (PRI) to cover for the risks caused by host States' measures during economic collapses. ${ }^{27}$ However, IIAs do not condition the existence or extent of investors' standards of protection to the possibility of the acquisition of such insurance. Both the insured investor and the investor that has decided not to insure, i.e. to self-insure, enjoy the same level of protection. Thus, economic efficiency can neither trump the obligation to compensate nor the introduction of cost-sharing mechanisms.

Second, even if an investor gets PRI, the coverage might not be enough to recoup all of the losses and the investor might still have to resort to investment arbitration to claim those losses, as Hochtief Aktiengesellschaft v. Argentine Republic clearly illustrates. ${ }^{28}$ Thus, room for costsharing mechanisms still might exist even when the investor uses market tools. Third, Kaplow himself acknowledges that the issue of fairness, cost sharing being one of its expressions, is not fully explored in his analysis. Thus, it cannot exclude the possibility of compensation in its entirety.

Finally, Kaplow's analysis is normative and exclusively economic. He acknowledges that there are norms protecting private property in the US Constitution that introduce cost sharing. ${ }^{29}$ However, he expresses that his analysis suggests 'the need for substantial re-evaluation of the basis for constitutional protection of property'. ${ }^{30} \mathrm{He}$ advocates changes to the existing rules. Such recommendations do not add much value to the reasoning suggested in this article because there are IIAs in place mandating compensation for investors, which cannot be ignored and which the present author does not question. ${ }^{31}$

In sum, the main propositions of this article remain in place after Kaplow's analysis.

\footnotetext{
${ }^{20}$ Louis Kaplow, 'An Economic Analysis of Legal Transitions', 99 Harvard Law Review (1986), 509, 531.

${ }^{21}$ See ibid. at $533-536$.

${ }^{22}$ See ibid. at 527-528.

${ }^{23}$ See ibid. at 535 .

${ }^{24}$ See ibid. at 529

${ }^{25}$ See ibid. at 577 .

${ }^{26}$ See ibid. at 577 .

${ }^{27}$ See Clint Peinhardt and Todd Allee, 'Political Risk Insurance as Dispute Resolution', 7 Journal of International Dispute Settlement (2016), 205, 216.

${ }^{28}$ See Hochtief Aktiengesellschaft v. Argentine Republic, Decision on Liability, ICSID Case No. ARB/07/31, 29 December 2014, at para. 309 [Hochtief].

${ }^{29}$ See Kaplow, supra note 20, at 553-566.

${ }^{30}$ See Kaplow, supra note 20, at 566.

${ }^{31}$ Kaplow's argument based on economic efficiency does not defeat the main proposition of this article based on reasonableness and fairness. However, his argument still could have an influence on the extent to which cost-sharing mechanisms could be deployed. For instance, in hypothetical terms, tribunals embracing the efficiency logic would be less willing to put in
} 
However, one of the topics Kaplow mentions that could be of direct relevance to the issue of cost sharing advocated here is that legal reforms create not only losses but also gains. ${ }^{32}$ In the context of economic crises, a host State may adopt some measures that adversely affect foreign investors and other measures that create gains or profits for the investors. The tribunal in El Paso Energy International Company v. the Argentine Republic dealt with this situation. The profits were assessed at the time the tribunal was measuring the compensation to be paid to the investor. The tribunal discounted the profits the investor had made as a result of other Argentinean measures. ${ }^{33}$

It can be stated that significant gains for investors should reduce the need to use cost-sharing mechanisms in the event a defence based on the NPM clause is successful. Indeed, no compensation will be paid to the investor as a result of this success, but the cost-sharing mechanism put forward might not be necessary in light of the significant gains enjoyed by the investor due to other measures.

On the contrary, if the defence based on the customary rule of necessity fails and the host State has to compensate the investor, the gains will be taken into account and reduce the size of the compensation, as in El Paso, and depending on their magnitude might or might not justify the use of the cost-sharing mechanism suggested here.

As was said, one way to introduce cost-sharing mechanisms is through the determination of the length of the economic crisis, using its start and end dates. I'll commence with the latter.

\section{Defining the End of a Crisis as a Risk-Sharing Mechanism in the Application of NPM Clauses or the Customary Rule of Necessity}

\subsection{Why Is the Decision on When a Crisis Ends So Important in the Architecture of NPM Clauses and the Customary Rule?}

In investment litigation involving economic collapses and NPM clauses or the customary rule of necessity, when the crisis ceases to exist is a determination that has profound implications for both host States and foreign investors. It marks the end of the special privileges that the former enjoyed during the crisis, if the requirements of the provisions were met, and from there on, the protection the international investment agreement accords to investors is reestablished in its entirety. The $L G \& E$ tribunal put it in unequivocal terms:

The third issue is related to what Argentina should have done, once the state of necessity was over on 26 April 2003. The very following day (27 April), Argentina's obligations were once again effective. $^{34}$

Consequently, the selection of the date on which a crisis ends plays a fundamental role within the operation of IIAs in general. The complexity that investor/State tribunals face when making the selection was recognized, in its decision on liability, by the Hochtief tribunal:

Fixing a date for the 'end' of an economic crisis is a highly subjective exercise ... [T] he selection of such a date does not signify the possibility of making a precise objective determination of a date on which the economic crisis ended: rather, it signifies the exercise by a

\footnotetext{
place cost-sharing mechanisms for the benefit of foreign investors or would narrow the scope of such mechanisms, in the event of host States' successful defences based on the applicable NPM clause.

${ }^{32}$ See Kaplow, supra note 20, at 552

${ }^{33}$ See El Paso Energy International Company v. the Argentine Republic, Award, ICSID Case No. ARB/03/15, 31 October 2011, at paras. 716 and 737 [El Paso].

${ }^{34} L G \mho E$, supra note 5, at para. 265. The El Paso tribunal speaks of the lack of application of the applicable IIA during the period of emergency. See El Paso, supra note 33, at para. 612.
} 
tribunal of its power to decide a case on the evidence before it, and the need to stipulate a particular date in order to give effect to the tribunal's reasoned judgment. ${ }^{35}$

This is, however, not to say that a decision on when the end of the crisis occurred must be made every time there is an investor/State dispute related to an economic collapse and a defence based on the NPM clause, or the customary rule has been raised by the host State. Many decisions regarding the Argentinean breakdown have been rendered in which the adjudication of the controversy has not required a determination of this nature. ${ }^{36}$

\subsection{The Determination on the End of a Crisis: The Experience of the Argentinean Saga}

Repetidas veces me digo que no hay otro enigma que el tiempo, esa infinita urdimbre de ayer, del hoy, del porvenir, del siempre y del nunca. (Jorge Luis Borges) ${ }^{37}$

Evidence of the intricacy of time in the context of NPM clauses and the customary rule of necessity is the fact that tribunals were not initially uniform regarding the length of the crisis. In effect, the first tribunal rendering a decision prompted by Argentina's 2001 crisis, CMS v. Argentine Republic, stated that in light of the economic information available, the Tribunal considers that sometime between late 2004 and early 2005 the crisis period came to an end'. ${ }^{38}$

The $L G \& E$ tribunal found the duration of the Argentine crisis to be much shorter than did the $C M S$ tribunal. According to the $L G \& E$ tribunal, and without any major analysis, the economic collapse ended on 26 April 2003, with the election of President Kirchner. ${ }^{39}$ This date, or another distant by a handful of days, became the date of the end of the economic breakdown for other tribunals, such as the Continental tribunal, ${ }^{40}$ the Total tribunal, ${ }^{41}$ the $A W G$ tribunal, ${ }^{42}$ and the Hochtief tribunal. ${ }^{43}$ The date was finally endorsed by Argentina itself in litigation by one of its own experts. ${ }^{44}$

In general, arbitration tribunals should use their discretion to determine the end of an economic collapse to allocate some risks and costs between foreign investors and host States during such events. There is evidence that this has been the effect of some awards in the aftermath of the Argentinean turmoil.

The purpose of what follows is to explore the different dimensions of these decisions and draw lessons useful to other investor/State tribunals dealing with disputes originating in other economic collapses and applying the case law on NPM measures or the customary rule.

\subsection{Expansion of the Length of the Crisis and the Failure of Defences Based on the Customary Rule}

It was shown that the CMS deemed that the crisis had lasted until some time at the end of 2004 or beginning of $2005 .{ }^{45}$ The CMS tribunal took this expansive approach in order to allocate costs to

\footnotetext{
${ }^{35}$ Hochtief, supra note 28 , at paras. 293-294.

${ }^{36}$ For instance, assessing the requirements for the invocation of the defence, in particular, the very existence of the crisis does not necessarily imply a determination on when it ended. Tribunals have recognized the existence of the Argentinean crisis without determining when it finished.

See, among others, National Grid, supra note 12, at paras. 258-262; Impregilo, supra note 12, at paras. 348-350; EDF, supra note 12, at para. 1172; and El Paso, supra note 33, at paras. 649-655.

${ }^{37}$ 'Over and over I told myself that time - that infinite web of yesterday, today, the future, forever, never - is the only true enigma,' Jorge Luis Borges, There are More Things (1975[1977]).

${ }^{38} \mathrm{CMS}$, supra note 12 , at para. 250.

${ }^{39}$ See $L G \ll E$, supra note 5, at para. 230.

${ }^{40}$ See Continental, supra note 4 , at para. 157.

${ }^{41}$ See Total Decision on Liability, supra note 12, at para. 171.

${ }^{42}$ See $A W G$, supra note 12 , at para. 257.

${ }^{43}$ See Hochtief, supra note 28, at para. 295.

${ }^{44}$ See ibid.

${ }^{45}$ See supra note 38 and accompanying text.
} 
the investor during the crisis when calculating the compensation to be paid to the claimant, since Argentina's defences based on the NPM clause and the customary rule had failed. ${ }^{46}$ The tribunal explicitly stated that allocation of costs between the investor and the host State was a factor in the calculation of the compensation. The CMS tribunal stated:

The factual situation ... allows the Tribunal to take into account different situations at distinct periods in time. The crisis had in itself a severe impact on the Claimant's business, but this impact must to some extent be attributed to the business risk the Claimant took on when investing in Argentina, this being particularly the case as it related to decrease in demand. Such effects cannot be ignored as if business had continued as usual. Otherwise, both parties would not be sharing some of the costs of the crisis in a reasonable manner and the decision could eventually amount to an insurance policy against business risk, and outcome that, as the Respondent has rightly argued, would not be justified. On the other hand, a number of the measures adopted did indeed contribute to such hardship and the burden ought not to be placed on the Claimant alone. ${ }^{47}$

Further in the award, the CMS tribunal reiterated that 'the crisis cannot be ignored and it has specific consequences on the question of reparation'. ${ }^{48}$ Then, when the tribunal was estimating the demand for gas and revenues, it dealt with the investor's claim that the demand would not have been affected by the crisis and rejected this assumption by stating:

The Tribunal has concluded that it is reasonable to assume that sales revenues would have decreased by $5 \%$ in each of 2002 and 2003 and by $1 \%$ in 2004 . This would reflect the delayed impact of the decline of the Argentine GDP in $2001(-4.4 \%)$ and $2002(-10.9 \%) .{ }^{49}$

As can be seen, the length of the crisis can be expanded for the purpose of reducing to a certain extent the compensation by taking into account the impact that the crisis would have had in any case on the investor. In this way, a cost-sharing mechanism is introduced. The defence based on the economic collapse failed, but this did not mean that the crisis was ignored and that the investor did not share some of the costs. ${ }^{50}$

The CMS tribunal deserves to be commended for this cost-sharing approach. It should be applied whenever it has been demonstrated that the economic collapse would have had an adverse impact on the investor, by reducing demand for its goods and services or of those in which the investment was made, or in other situations.

It could be argued that, particularly in the event of the failure of the defence, resulting from the host State's contribution to the economic collapse, the measure of the compensation should not take into account such event. ${ }^{51}$ The argument would be misleading on two accounts. First, claimant investors should not double dip. They got the benefit of the existence of the contribution and of the failure of the defence; therefore, compensation is due to them. Ignoring the crisis when the

\footnotetext{
${ }^{46}$ See CMS, supra note 12, at paras. 315-331 and 353-378. An Ad Hoc Annulment Committee was very critical of the CMS tribunal's legal interpretation of the NPM clause and the customary rule. See CMS Annulment Decision, supra note 3, at paras. 129-136. However, this criticism had no impact on the decision of the tribunal regarding the length of the crisis and on the measure of the compensation.

${ }^{47} \mathrm{CMS}$, supra note 12 , at para. 248.

${ }^{48}$ Ibid., at para. 406.

${ }^{49}$ Ibid., at para. 446 .

${ }^{50}$ It is important to say that the CMS tribunal is not the only one that has taken the crisis into account at the time of measuring the compensation. The Hochtief tribunal also did so. See Hochtief, supra note 28, at paras. 317-318.

${ }^{51}$ The requirement of lack of contribution is explicitly provided for by the customary rule of necessity. However, some tribunals dealing with NPM clauses have also included the requirement within such clauses. See Continental, supra note 4, at para. 234; and El Paso, supra note 33, at paras. 617-624.
} 
compensation is measured would be a second benefit for the very same reason. Second, taking into account the crisis when measuring damages sometimes reflects an economic reality: the crisis would have had an adverse impact on the investor even if the measures it complained about had not been adopted. As the CMS tribunal pointed out, this is a business risk that the investor should bear.

Finally, taking the crisis into account when measuring the compensation could go beyond the recognition of this economic reality. In effect, this estimation is always a matter of reasonableness, ${ }^{52}$ and this notion also changes according to the circumstances. There is a notion for reasonableness in measuring compensation in normal times, and there is another in times of emergency.

\subsection{Contraction of the Duration of the Crisis and the Success of a Defence Based on an NPM Clause}

The length of the crisis can be contracted as a cost-sharing strategy as well when the defences are successfully invoked. By virtue of the operation of the defences, setting the period between the start and end dates of the crisis at the shortest length possible while recognizing the existence of severe economic strain allows tribunals to alleviate the burden of the risks borne by foreign investors, since once the crisis is considered finished, full compensation is due to them and the risks are shifted to host States, even if their economic situation may not be totally normal. ${ }^{53}$

The $L G \& E$ tribunal took this approach. Although the $L G \& E$ tribunal declared that the crisis met the requirements of Article XI, the applicable NPM clause, and that no compensation was due to the investor during its duration, ${ }^{54}$ the tribunal significantly narrowed the length of the necessity when calculating the damages due by Argentina to LG\&E, until 26 April $2003 .^{55}$ The previous tribunal had determined in the CMS case that it was somewhere at the beginning of $2005 .^{56}$ Full compensation was calculated from the date the $L G \& E$ tribunal declared that the state of necessity had ceased to exist and Argentina should have started meeting its obligations to the investor, which it had not. ${ }^{57}$

The definition of the length of the crisis is also important for the sharing of risks in another way when the NPM clause is successful: investors might be affected not by a single measure but by a set of measures adopted at different times. A narrow definition of the length of an economic collapse catches some measures, and States would not have to pay compensation on account of them, while the later-in-time measures would fall outside of the crisis, and investors would have to be fully compensated in respect of these latter measures. ${ }^{58}$ This is the effect the Continental tribunal achieved after declaring the success of the NPM clause. ${ }^{59}$ Contrary to what the CMS tribunal had stated, according to which the crisis had ended somewhere at the end of 2004 or the beginning of 2005, the Continental tribunal stated that Argentina was evolving towards normality

\footnotetext{
${ }^{52}$ The Total tribunal stated that it had some discretion to award 'damages in a reasonable amount', Total S.A. v. the Argentine Republic, Award, ICSID Case No. ARB04/1, 27 November 2013, at para. 32.

${ }^{53}$ This proposal does not suggest that tribunals should always shorten the length of crises. It could be a tool to be used when tribunals declare the success of the invocation of the NPM clause and, in light of the particular facts of the case, are of the view that some cost-sharing mechanisms between the given claimant investor and the host State must be introduced for the purpose of achieving a reasonable compensation.

${ }^{54}$ See $L G \ll E$, supra note 5, at para. 260.

${ }^{55}$ See ibid., at para. 226.

${ }^{56}$ See $C M S$, supra note 12 , at para. 250.

This is, however, not to say that only tribunals that found the invocation of the NPM clause or the customary rule successful are the ones that fixed this date, April 2003. The $A W G$ tribunal agreed on the $L G \& E$ tribunal's date of the end of the crisis as was said, but concluded that Argentina had not met the requirements of the customary rule. See AWG, supra note 12, at paras. $263-265$.

${ }^{57}$ See supra note 34 and accompanying text.

${ }^{58}$ See Continental, supra note 4 , at paras. 159 and 220.

${ }^{59}$ See ibid., at paras. $160-219$.
} 
in September 2004. Thus, a measure affecting the investor and adopted on 9 December 2004, was not covered by the success of the clause, ${ }^{60}$ and compensation was due to the investor. ${ }^{61}$

As can be seen, there was a crisis and the respondent's defence based on the NPM clause was successful, but the shortening of the length of the economic collapse allowed the investor to get some compensation. A similar situation can be achieved when the customary rule is also successful. Although, by virtue of the success, the investor could still negotiate compensation for material losses during the crisis with the host State, full compensation would be owed to the former for damages caused by measures adopted after the economic turmoil ceased in the tribunal's view. The compensation could be assumed to be higher the earlier the crisis was deemed to have ended, and costs would then be allocated on host States despite the success of the customary defence.

\subsection{Research in Economics on the End of Economic Crises}

The end of economic crises has received significant attention in economics, and this paper turns to this body of research to show how it could be used to mitigate to a certain extent the strictures of the case law on NPM clauses and the customary rule of necessity.

The first approach in economics on the conclusion of economic collapses is to declare that a crisis has ended only once a certain criterion had reached its pre-crisis level. Harvard's Reinhart and Rogoff deem that a crisis ends whenever an economy reaches 'the prior peak in real per capita income'. ${ }^{62}$ This was the indicator and the level they used when they assessed the length of 100 financial crises around the world. The International Monetary Fund agrees with this approach. ${ }^{63}$

However, some economists have been cautious about making the return to a pre-crisis level as the parameter that signals the end of a breakdown. For instance, Fatás and Mihov have illustrated that, if the length of the US 1981 recession is measured by the time that the output gap took to reach its pre-crisis level, the output took 20 quarters to get there, when the fact is that the gap had been very close to zero after seven quarters. A similar situation took place, these authors claim, regarding the US 1991 recession. The output gap took 25 quarters to get the pre-crisis level; however, the gap was, again, close to zero after seven quarters. ${ }^{64}$

The legal implications of these two approaches in economics can be substantial for host States and foreign investors if the invocation of the NPM clause or the customary rule is successful. If a fixed level is chosen as a determinant of the end of a crisis, its length may be significant in the event of situations in which the given criteria have been close to their pre-crisis level for a certain period of time and on a consistent basis. In this case, the economy has recovered, even if the chosen criteria have not reached their pre-crisis level. The full application of the Reinhart and Rogoff approach - that an economic collapse is deemed to have ended only when a particular criterion or criteria have reached their pre-crisis level - would mean that States would enjoy, for instance, the benefits of the NPM clause and its zero-compensation effect for longer periods of time; measures adversely affecting foreign investors adopted during this lapse of time would not violate the given IIA. Instead, under the approach suggested by Fatás and Mihov, crises end when the recovery trend becomes consistent, even if the given criterion has not reached the exact pre-crisis level.

\footnotetext{
${ }^{60}$ See ibid., at paras. $220-22$.

${ }^{61}$ See ibid., at para. 320 (B).

${ }^{62}$ Carmen M. Reinhart and Kenneth S. Rogoff, 'Recovery from Financial Crises: Evidence from 100 Episodes', NBER Working Paper No. 19823, January 2014, at 4, www.nber.org/papers/w19823.pdf.

${ }^{63}$ Kannan, Scott, and Terrones define the recovery and its length 'as Number of quarters after trough and before recovery to the level of previous peak'. Prakash Kannan, Alasdair Scott, and Marco E. Terrones, 'From Recession to Recovery: How Soon and How Strong', IMF World Economic Outlook, April 2009, at 6 n. 3, www.imf.org/external/np/seminars/eng/2012/ fincrises/pdf/ch8.pdf.

${ }^{64}$ See Antonio Fatás and Ilian Mihov, 'Recoveries', Paper presented at the annual conference of the Boston Federal Reserve, 12-13 April 2013, at 17, https://faculty.insead.edu/fatas/Recoveries\%20Fatas\%20Mihov.pdf.
} 
The latter approach is the one suggested in this article to introduce a risk-sharing mechanism between host States and foreign investors during economic collapses and in the event of the successful invocation of NPM clauses or the customary rule. These events should be deemed to have ended once the economy has started on a consistent path toward full recovery. Consequently, measures adopted by host States during this period should not get the benefit of the provisions, even if the selected economic criteria have not totally reached their pre-crisis level, and compensation is owed to investors by host States. There was a glimpse of this approach in the Continental award. There, the tribunal assumed that the crisis had virtually ended once Argentina had returned to the US financial markets, which was evidence that its financial conditions 'were evolving towards normality'. ${ }^{65}$

In addition, when tribunals are relying on several criteria to determine when the crisis in question ended, they should not declare the end of a crisis only after all of the criteria are on the path to reaching pre-crisis levels. Although one can expect that the criteria would be somehow interconnected in their evolution, not all of them will have the same dynamic. ${ }^{66}$ Waiting for the last of them to be set onto a path to its pre-crisis level would extend the length of the crisis more than is necessary, and States should not have the benefit of the zero-compensation effect of NPM clauses when the economic climate has considerably improved and there is no significant risk involved. There are some traces of this approach in the CMS, Continental, and Hochtief decisions. ${ }^{67}$

\section{Risk-Sharing Mechanisms in 'Double Dipping Crises'}

Macroeconomic research has identified a certain situation not uncommon in economic crises that warrants particular attention when narrowing the length of an economic collapse in the event of a successful defence based on an NPM clause or the customary rule. In effect, Reinhart and Rogoff have shown that a significant percentage of financial crises in the United States have had what these economists call double dipping: a crisis began; an upturn in economic activity, which did not reach the previous peak, during a short period of time took place; and then the economy took a renewed downturn before it started recovering again and finally reached the pre-crisis peak. $^{68}$ In other words, there was a short-lived recovery that was not sustained. Reinhart and Rogoff treat the whole episode as a single crisis. However, as these authors highlight, their approach differs from another in which, instead of one crisis, economists regard that the given economy faced two crises separated by a period of time, that is, the first upturn. ${ }^{69}$ The key issue is how to treat those measures affecting foreign investors adopted by host States during the first upturn.

Both approaches have different legal implications for States and investors. If a tribunal embraces the Reinhart and Rogoff approach, all of the measures adopted by a State during the short-lived upturn will be covered by the NPM clause and its zero-compensation effect. However, if the other approach is the one embraced, then the measures adopted sometime during the first upturn would have not been adopted during the time of necessity, and therefore, they would not be covered by the NPM clause or the customary rule. Thus, investors would have to be compensated in full for damages caused by measures adopted during most of the length of the first upturn.

It is certainly up to a tribunal, depending on the facts, the duration of the first upturn, and its degree, to make a decision in this regard, but a tentative analysis is worth making. The first

\footnotetext{
${ }^{65}$ See Continental, supra note 4, at paras. 159 and 221 , n. 336.

${ }^{66}$ Relying on the theory of business cycles, Rebelo illustrates the phenomena of comovement of different sectors of the US economy regarding several criteria, such as gross output, value added, and materials and energy use. See Sergio Rebelo, 'Real Business Cycle Models: Past, Present, and Future’, NBER Working Paper No. 11401, June 2005, 19-21. Comovement could also be at play during recoveries.

${ }^{67}$ See CMS, supra note 12, at para. 249; Continental, supra note 4, at para. 152; and Hochtief, supra note 28, at para. 294.

${ }^{68}$ See Reinhart and Rogoff, supra note 62, at 4.

${ }^{69}$ See ibid.
} 
upturn meant that the economy was just attempting to return to its pre-crisis level, and the fact that it was followed by a downturn meant that the economy, even at the time of the upturn, still faced significant risks. Thus, measures adopted during the first upturn should still be considered to have been necessary to overcome the given crisis in a more general sense. There would be, then, in principle, powerful reasons to regard that, during the short-lived recovery, the host State could still get the benefit of the NPM clause or the customary rule regarding measures adopted therein. As Reinhart and Rogoff suggest, the situation should be treated as a single crisis.

This assessment leads to the issue of how to narrow the length of a crisis in double-dipping economic collapses. As was said above, following Fatás and Mihov, ${ }^{70}$ tribunals should not wait to define the length of the crisis until the date the pre-crisis level was reached, but they could assume that the economy was not at grave risk at the time when the second upturn was strong and consistent in indicating a clear path to full recovery.

This is not, though, the end of the usefulness of the research in economics for investor/State tribunals. Reinhart and Rogoff can equally be important to tribunals in the event of the failure of the invocation of NPM clauses or the customary rule. Again, this research can show tribunals how long the full recovery took and can give them a more precise idea about the length of the impact of the crisis on the investor as a matter of economic reality, due, for instance, to a drop in demand for the investor's goods or services.

There should be no problem for tribunals in relying on both types of research in economics, since they will never be used at the same time, obviously, and they will be used for different purposes - to determine the end of the protection accorded to host States under situations of emergency or the calculation of damages - and in different legal circumstances, one in the event of successful invocation of the defence, the other, in the event of its failure.

\section{Tribunals' Decision on When an Economic Collapse Starts, as a Risk Allocation Tool}

The LGeE tribunal and the tribunal in Urbaser S.A. and Consorcio de Aguas Bilbao Bizkaia, Bilbao Biskaia Ur Partzuergoa v. The Argentine Republic made a determination on the beginning of the Argentinean crisis. The former said that the collapse ran from 1 December 2001. ${ }^{71}$ The latter said that it ran from June/July $2001 .^{72}$

Fixing the date that marks the commencement of an economic breakdown by tribunals can also have the effect of allocating risks and costs between host States and investors.

\subsection{Fixing the Date of the Beginning of the Collapse for the Benefit of the Foreign Investor}

Fixing the date of the beginning of a crisis is fundamental in the event of the successful invocation of the applicable NPM clause or the customary rule: the host State is excused from liability for any breaches of the applicable treaty from the date the economic breakdown started until the date it ended. ${ }^{73}$

A tribunal can set the date in a way that achieves some allocation of risks. If it defines the beginning of the crisis later in time, losses suffered by the investor, as a result of measures adopted prior to when the crisis started, as decided by the tribunal, are fully compensated. Again, the defence is successful for the benefit of the host State, but it still incurs some costs for the benefit of the foreign investor.

\footnotetext{
${ }^{70}$ See supra note 64 and accompanying text.

${ }^{71}$ See LG\&E, supra note 5, at paras. 226-229.

${ }^{72}$ See Urbaser S.A. and Consorcio de Aguas Bilbao Bizkaia, Bilbao Biskaia Ur Partzuergoa v. The Argentine Republic, Award, ICSID Case No ARB/07/26, 8 December 2016, at paras. 250-256 and 263 [Bizkaia].

${ }^{73}$ See $L G \& E$, supra note 5, at para. 229.
} 


\subsection{Fixing the Date of the Beginning of the Collapse for the Benefit of the Host State}

Fixing the date can also play an important role in the event of a failure of a defence of the NPM clause or the customary rule under certain circumstances, as the Argentinean saga illustrates.

Determining the date might be important for the investor, depending on when she made the investment. Thus, if the investment was made, in the tribunal's view, shortly before the crisis erupted, such circumstances might affect the expectations that the investor could have had at the time of the investment under the applicable fair and equitable treatment obligation (FET) ${ }^{74}$ There is evidence of this situation in the Total tribunal's decision on liability.

The Total tribunal dealt with an investor's claim of violation of the FET as a result of substantial changes, in its view, to Argentina's electricity regulation. ${ }^{75}$ Total was claiming that the regulatory changes had affected its legitimate expectations. ${ }^{76}$ The Total tribunal noticed that the investor had made its investment in September 2001, when the Argentinean economy had significant economic and financial problems, ${ }^{77}$ and just a few months before the explosion of the crisis'. ${ }^{78}$ The Total tribunal then concluded that some of the changes to the regulatory framework - in particular, the fixed parity between the peso and the US dollar - could be abandoned without their being a violation of the applicable FET. The Total tribunal concluded that 'this context should have influenced Total's expectations when making its investments.' ${ }^{79}$ Argentina then did not have to compensate the investor for the losses to the investor caused by this measure.

This is not to say that making the investment shortly before a crisis erupts leaves foreign investors totally unprotected in the sense that they are assuming all of the risks during the collapse. The Total tribunal's decision on liability did not produce this effect. Despite the above-mentioned timing of the investment, the Total tribunal found that other measures had violated the applicable $\mathrm{FET}^{80}$ and, therefore, that full compensation was owed to the investor, since Argentina's defence based on the customary rule had failed. ${ }^{81}$

The Total tribunal's decision on liability leaves a lesson: a tribunal determines when a crisis started, and if the investment is made shortly before the collapse began, the fact that the host State's defence fails does not mean that the costs of the collapse will be borne by the host State only. The timing of the investment might mean recognition by the tribunal that some of the investor's expectations were not reasonable and, therefore, that it is the investor who has to bear the costs of certain measures that, for the reason of the timing of the investment, might not be contrary to the applicable FET. Thus, determining when the breakdown began is instrumental for the cost-allocation effect of the decision.

\section{Impregilo: New Dimensions to the Total Tribunal Approach}

The Impregilo award, rendered after the Total Decision on Liability, and the particular facts of the case add new layers of analysis to how to assess investments made shortly before a crisis erupts for

\footnotetext{
${ }^{74}$ The words of the main character, an investment banker, in Jorge Volpi's novel Memorial del Engaño (Memoir of a Fraud) come to mind:

Y le dije qué teníamos que hacer ... debíamos sacar partido de ese mínimo paréntesis, de esa oportunidad de oro, el preludio del desorden, apostar aquí y allá [So I suggested what to do ... we should take advantage of this brief parenthesis, of this golden opportunity, the prelude of the mess, making bets here and there].

${ }^{75}$ See Total Decision on Liability, supra note 12, at para. 305.

${ }^{76}$ See ibid., at para. 297.

${ }^{77}$ See ibid., at paras. $322-323$

${ }^{78}$ See ibid., at para. 322.

${ }^{79}$ See ibid., at para. 324 .

${ }^{80}$ The measures set prices that did not allow the investor to recover its costs and make a reasonable profit, as mandated by the Argentinean legal system. See ibid., at para. 333.

${ }^{81}$ See ibid., at paras. $222-224$.
} 
the purpose of cost allocation, even if Total is not mentioned for this purpose. ${ }^{82}$ The dispute was related to an investment made in a company, Aguas de Buenos Aires (AGBA), in December 1999, that was awarded a concession contract ${ }^{83}$ two years before the beginning of the Argentinean collapse according to $L G \& E$. The Impregilo tribunal found (i) that omissions by Argentina had led to miscalculations of the risks of the project by the investor; ${ }^{84}$ (ii) that before the crisis Argentina had failed to comply with obligations under the contract that were instrumental to the investor's company's compliance with its own commitments; ${ }^{85}$ (iii) that the investor had had overoptimistic expectations regarding the profitability of the contract; ${ }^{86}$ and (iv) that Argentina's measures to deal with the economic breakdown had violated the applicable FET. ${ }^{87}$

Then, the Impregilo tribunal moved on to calculate the compensation owed to the investor. The tribunal achieved a balanced result: it allocated costs to both parties. The remedy that the Impregilo tribunal imposed was restitution. Argentina had to restitute only the investment made by Impregilo in AGBA plus interest. ${ }^{88}$ Although Impregilo claimed damages based on the expected gains from the contract, the tribunal concluded that part of the problem of the concession was due to an unrealistic forecast by AGBA: the area had a poor population not used to paying for the services. ${ }^{89}$ In the tribunal's view, these elements were part of the business risk that AGBA had to bear. ${ }^{90}$

The Impregilo tribunal was silent on the timing of the investment, which suggests that the tribunal did not consider that the timing was such that the investor was taking a higher risk, even if by December 1999 Argentina was already under significant stress and showing the early signs of its economic breakdown. ${ }^{91}$ Regardless of whether or not one shares this determination, the Bizkaia tribunal did not, as will be shown below, the Impregilo tribunal had grounds to support the silence when exercising its judgment on the topic. The investment was made two years before the crisis erupted, according to the $L G \& E$ and the Total tribunals. It is true that the early manifestations of the crisis were already taking place. However, not all recessions lead to economic collapses triggering NPM clauses or the customary rule, so it could be said that at the time of the investment Impregilo was not assuming risks beyond what could be considered only business risks for a long-term transaction.

It is also important that the investor's behaviour in terms of unrealistic expectations is taken into consideration at the time the tribunal measures compensation. So, the fact that the defence based on necessity is rejected, as in Impregilo, does not mean that the tribunal will ignore any investor's contribution to its losses. This is certainly a well-known principle of the law of damages in international law, ${ }^{92}$ but it is important to note its application in investor/State arbitration dealing with economic collapses.

\footnotetext{
${ }^{82}$ The Impregilo tribunal was dealing with a dispute regarding the alleged violation of the Agreement between Italy and the Argentine Republic for the Promotion and Protection of Investments (Argentina-Italy BIT). See Impregilo, supra note 12, at para. 5.

${ }^{83}$ See ibid., at paras. 1,14 , and 237. Impregilo owned $42,58 \%$ of AGBA's stock and made a USD 21.3 million equity investment in the latter company (see ibid., at para. 238). Measures adopted by Argentina to cope with its collapse affected the contract and the investor. The contract was terminated by Argentina in July 2006 (see ibid., at paras. 45 and 48 ).

${ }^{84}$ See ibid., at para. 251.

${ }^{85}$ See ibid., at para. 254.

${ }^{86}$ See ibid., at para. 373.

${ }^{87}$ See ibid., at paras. 330-331.

${ }^{88}$ See ibid., at para. 379.

${ }^{89}$ See ibid., at para. 373.

${ }^{90}$ See ibid., at para. 374 .

${ }^{91}$ At this time, Argentina's economy was already in a recession as a result of the adverse consequences caused by the Asian crisis of 1997 and the Brazilian crisis of 1999, as the International Monetary Fund admitted at the time (see International Monetary Fund PIN No. 00/84, IMF Concludes Article IV Consultation with Argentina, 3 October 2000), www.imf.org/ en/News/Articles/2015/09/28/04/53/pn0084.

${ }^{92}$ See Article 39 of the ILC's Articles on State Responsibility. See ILC's Articles, supra note 6, at 9.
} 
It is equally worth mentioning that the Impregilo tribunal also looked at Argentina's behaviour before the crisis erupted and noted the fact that its omissions contributed to the miscalculations of risk and to investor's losses. This factual situation was not present in Total. In sum, Impregilo can be deemed as expanding the conceptual analysis tribunals should carry out when the investor has made its investment shortly before an economic crisis erupts and the defence of necessity has failed: investors' and host States' actions and omissions before the collapse should be assessed either to assess the scope of the FET in light of the relevant facts or to measure the compensation.

\section{Bizkaia: Investor's Due Diligence as an Additional Element}

The Bizkaia tribunal, which dealt with the same concession contract and facts of the Impregilo dispute, ${ }^{93}$ but a different IIA, ${ }^{94}$ went even further than Total in 2016 by defining the beginning of the crisis much earlier than did the LGe $E$ tribunal. The Bizkaia tribunal found that the crisis that led to the emergency measures adopted by Argentina began in mid-1998. ${ }^{95}$ Contrary to Impregilo, the Bizkaia tribunal was not silent, and the timing of the investment was one of the factors, although not the most important, that the tribunal took into account when it assessed the scope of the protection the investor had under the FET standard. ${ }^{96}$ As in Impregilo, the Bizkaia tribunal found that the investor's decisions were determinant to the problems the Concession Contract was having before the Argentinean measures were adopted. Such decisions should have an impact on the assessment of the protection accorded by the FET standard. According to the tribunal:

the investor's protection for fair and equitable treatment cannot make contracts better than they were, nor can it restore rights or expectations that the investor has waived or lost due to its own negligence. ${ }^{97}$

However, the Bizkaia tribunal held a different view regarding the role that the host State's actions and omissions had had on the investor's miscalculations of risks. The Bizkaia tribunal did not stop at the identification of those acts and omissions. In a very important finding, the tribunal assessed whether an experienced investor could have, on the basis of the proven facts and due diligence, avoided the miscalculation. It concluded that it could. ${ }^{98}$ The Bizkaia tribunal also carried out a deeper assessment than that of the Impregilo tribunal as to the host State's actions and omissions that could have had an impact on the investor's compliance with its obligations. After a careful evaluation of the text of the concession contract, the tribunal was of the view that Argentina's omissions should not have prevented AGBA from complying with the contract. $^{99}$ The investor had also claimed that the impossibility of getting loans to finance AGBA's investment commitments was due to Argentinean authorities' omissions and to the crisis. ${ }^{100}$ After a detailed evaluation of the contract and of the evidence, the tribunal concluded that such impossibility was unrelated to any Argentinean action. ${ }^{101}$

\footnotetext{
${ }^{93}$ See Bizkaia, supra note 72 , at para. 34 .

${ }^{94}$ The claimants in Bizkaia were also shareholders of AGBA, and the value of their shares was US45 million (see ibid., at para. 383). The applicable IIA was the 'Agreement on the Reciprocal Promotion and Protection of Investments between the Argentine Republic and the Kingdom of Spain' signed on 3 October 1991. See Bizkaia, supra note 72, at para. 1.

${ }^{95}$ See ibid., at para. 634 .

${ }^{96}$ See ibid., at para. 638.

${ }^{97}$ See ibid., at para. 630 .

${ }^{98}$ See ibid., at paras. $250-256$ and 263.

${ }^{99}$ See ibid., at paras. $368-370$.

${ }^{100}$ See ibid., at para. 408.

${ }^{101}$ See ibid., at paras. 434-435.
} 
Although, the Bizkaia tribunal recognized the existence of a violation of the FET as a result of Argentina's omissions during the renegotiation of the contract, ${ }^{102}$ the tribunal did not order Argentina to pay any compensation. ${ }^{103}$ The reason: the concession was already in severe difficulties before the measures were taken by Argentina, because of the investor's own decisions. ${ }^{104}$ In this sense, the effect of Bizkaia is not cost sharing, since the costs fell on the investors only. The tribunal should not be criticized for this effect, since it arose from the particularities of the case: the contract transferred significant risks to the concessionaire, ${ }^{105}$ on one hand, and, on the other, the shareholders' decisions were a fundamental cause of the problems before the measures were adopted. ${ }^{106}$

Despite the differences in outcomes, the Impregilo and Bizkaia awards might add important considerations to the Total tribunal's allocation of costs to investors based on the timing of the investment. When the timing falls under the 'few months before the crisis' approach of the Total tribunal, tribunals should not stop there and apply the Total approach. Indeed, they should, in addition, (i) assess any investor's actions that has contributed to its losses, and (ii) assess whether or not the host State has carried out actions or omissions before the collapse that had an influence on the investor's assessments of its risks, but take into account whether proper due diligence and the sophisticated nature of the investor should have allowed it to avoid the miscalculation.

Over all, the combined approach of the three decisions constitutes a positive development: foreign investors claiming their rights before investor/State tribunals are presumed to be sophisticated and well informed, generally. If they make investments at a time that a severe economic crisis is close on the horizon, they are wilfully taking more risks, charging a premium for this action, and expecting higher returns. Consequently, it is reasonable for tribunals to allocate to these investors some of the costs caused by measures adopted by host States to cope with the breakdown that have been found to be contrary to the applicable IIA and not justified by defences based on an NPM clause or the customary rule.

Before concluding, there is an important issue to address: is the research in economics the best instrument to determine the beginning or the end of crises in all circumstances? Not necessarily. The facts of the case, the scope and accuracy of the economic data, and the strength of the models used will determine the value of such research to investor/State tribunals. The important issue put forward in this article is that the length of the economic collapse can be used to introduce a risksharing mechanism. Thus, the value of the research in economics is that it can be an important instrument at the disposal of tribunals to achieve this end.

There are, however, important dimensions that research in economics can add to the assessment of the length of economic crises by tribunals. Reflections on the Continental award show some of these dimensions.

To illustrate the existence of the crisis in Argentina, the Continental tribunal listed a set of deteriorating economic, social, and political events to show that the crisis was covered by the applicable NPM clause, but without indicating the extent of the adverse impact. ${ }^{107}$ The elements were the following: collapse of the economy, significant increase in inflation and in unemployment, half of the population falling below the poverty line, threat to the health of the young population, unrest, risk of insurrection, and resignation of successive presidents.

\footnotetext{
${ }^{102}$ See ibid., at paras. $843-845$.

${ }^{103}$ See ibid., at paras. $846-847$ and 1234.4 .

${ }^{104}$ See ibid., at paras. 638 and 678 .

${ }^{105}$ See ibid., at para. 512 .

${ }^{106}$ Bizkaia also illustrates what was mentioned at the beginning: that allocation of risks and costs is a not an effect that should always exist. Despite this, Bizkaia is quite useful to the deepening of the Total approach on cost sharing, as will be seen below.

${ }^{107}$ See Continental, supra note 4 , at para. 180.
} 
Then, the tribunal presented a set of criteria that had been improving since Argentina had reached the bottom of the crisis and the extent of the improvement, such as increase in the gross national product, no high inflation, improvement in the exchange rate and in the balance of payments, unilateral reduction of the domestic and international debts, and the competitiveness of Argentina's exports as a result of the $70 \%$ devaluation. ${ }^{108}$

The research in economics on the end of crises illustrated here may improve the analysis in several ways. First, the same elements that were used to illustrate the existence of the crisis should, in principle, be used to determine its end. This was not the case with the analysis of the Continental tribunal, as a straightforward comparison of the criteria reveals. The second is that showing that the crisis ended should not be based only on those criteria that evolved positively, as the Continental tribunal did, ${ }^{109}$ since such analysis may not grasp a complete picture of the situation at a particular time. The analysis should also include an illustration of those elements that were used to show the existence of the crisis and that had not recovered yet. Third, once the positive and negative criteria had been identified and assessed, tribunals should make a judgment.

Fourth, research in economics of the type cited here, which includes the evolution of certain economic criteria by quarters of a year to illustrate the evolution of the recovery, offers tribunals a reasoned argument to make a decision on the length of an economic collapse. Tribunals should go further and indicate the number of quarters that they regard as enough evidence of the recovery and, therefore, of the end of the given crisis. ${ }^{110}$

\section{In a Nutshell}

The current case law on NPM clauses, when they are successful, and the customary rule of necessity, when it fails, transfers significant risks to foreign investors and host States, respectively, during severe economic crises. Some risk-sharing mechanisms should be explored to try to achieve a more balanced result. The article has presented the policy reasons in support of this approach and the normative basis investor/State tribunals have to implement it: the principle of acceptable compensation. The piece has also illustrated that one way to introduce such mechanisms is through the determination of the length of the economic breakdown, which is marked by the dates of the beginning and end of the crisis. In this regard, the article starts with an analysis of the latter.

The article has presented the different approaches that in this regard held the case law of the Argentinean saga. The selection of the date of the end of a crisis can be used in two ways to allocate some risks and costs between foreign investors and host States during economic collapses this article has illustrated. First, when a host State's defence based on the NPM clause or the

\footnotetext{
${ }^{108}$ See ibid., at paras. $157-159$.

${ }^{109}$ To be fair to the Continental tribunal, it did mention some factors that had not evolved positively (see Continental, supra note 4, at para. 152). However, the factors did not make up part of the assessment that the tribunal carried out to determine when the economic collapse had ceased.

${ }^{110}$ It is expected that over time investor/State tribunals will arrive at a certain consensus on the number of quarters of recovery that could be deemed as enough to mark the end of a particular economic crisis for the purpose of deciding an investor's claim or host State's defence. Once this consensus is achieved, governments dealing with another ongoing crisis might at least have a reference point to make ex ante assessments regarding when future tribunals will regard that the economic breakdown ended. Even though economic collapses are different in their causes and effects, this consensus would then mitigate to some extent the uncertainty that governments face when crafting decisions aimed at curbing severe ongoing economic turmoil.

In effect, there is a certain consensus among tribunals that dealt with the Argentinean collapse. In general, the consensus on recovery is for the third or fourth quarters. The bottom of the crisis took place in the second or third quarter of 2002 (see Continental, supra note 4, at para. 152); and the breakdown ceased in the second quarter of 2003 (see supra notes 38 to 43 and accompanying texts).

Whether or not three or four quarters of recovery might be applied by investor/State tribunals to another crisis remains to be seen. But the point of reference is there for future governments to use as a gauge.
} 
customary rule has been unsuccessful, the length of the crisis can be expanded for the purpose of reducing to a certain extent the compensation by taking into account the impact that the crisis would have had in any case on the investor. Second, the shortening of the duration of an economic breakdown can also be an important tool to allocate risks between investors and host States when the defences are successfully invoked.

The article has then turned to research on economics on the end of crises and shown two main approaches and their legal implications on the application of NPM clauses and the customary rule. The article has illustrated how tribunals could use this research when contracting or expanding the length of the crisis for the purpose of the allocation of risks and costs during these events.

The article has continued by showing that fixing the date that marks the beginning of an economic breakdown by tribunals can also have the effect of allocating risks and costs between host States and investors. In particular, the article has illustrated how the case law of the Argentinean saga achieved this result in the event of the failure of the defence based on an NPM clause or the customary rule, when the investment had been made a few months before the start of the crisis.

Summarizing, the article has demonstrated that the assessment of the case law on NPM clauses and the customary rule of necessity should not stop at the interpretations of these provisions. The success or failure of the defence based on them might not tell the whole story about the allocation of costs during economic collapses as a result of the given decision. Indeed, the definition of the length of the crisis by international tribunals can have, and have in fact sometimes had, an important cost-sharing effect between host States and investors.

Acknowledgements. Early versions of this article were presented at the Joint North American Conference on International Economic Law organized by the American Society of International Law and the Canadian Council of International Law in Montreal in 2018 and at the 2018 Global Conference of the Society of International Economic Law held in Washington, DC. I wish to thank participants at these events for helpful discussions and to two anonymous referees for their encouraging and invaluable comments. I own all errors. The generous support of the Faculty of Law of the University of Waikato is acknowledged. This article is dedicated to Eliana Herrera, Leticia and Aluna Alvarez.

Cite this article: Alvarez-Jimenez A (2019). International Investment Law, Time, and Economics: Fixing the Length of Economic Crises as a Costs-Allocation Tool between Host States and Foreign Investors. World Trade Review 1-18. https://doi.org/10.1017/S1474745618000381 